\title{
Britain's Religious Tribunals: 'Joint Governance' in Practice ${ }^{+}$ \\ Russell Sandberg", Gillian Douglas ${ }^{* *}$, Norman Doe ${ }^{* * *}$, Sophie Gilliat-Ray ${ }^{* * * *}$ and Asma Khan ${ }^{* * * * *}$
}

Abstract - In recent years, there have been a number of moral panics in Western societies about the existence of religious courts and tribunals in general and Shariah law in particular. In England and Wales, these concerns came to the fore following the Archbishop of Canterbury's 2008 lecture on 'Civil Law and Religious Law in England'. In that lecture, the Archbishop drew upon the work of the Canadian scholar Ayelet Shachar endorsing her concept of 'transformative accommodation'. In this article, we return to the work of Shachar in the light of our recent empirical study which examined the divorce jurisdiction of three religious tribunals in detail: a Jewish Beth Din; a matrimonial tribunal of the Roman Catholic Church; and a Muslim Shariah Council. We suggest that the focus upon Shachar's concept of 'transformative accommodation' by the Archbishop and subsequent commentators is unfortunate given that Shachar actually proposes 'transformative accommodation' as just one variant of what she refers to as 'joint governance' (albeit her preferred variant). We propose that the umbrella concept of 'joint governance' and its other variants can be developed in a way that could prove to be more useful than 'transformative accommodation'.

Keywords: authority, constitutional theory, courts, multiculturalism.

\footnotetext{
${ }^{+}$This article is based upon research conducted as part of the 'Social Cohesion and Civil Law: Marriage, Divorce and Religious Courts' Research Project funded by the AHRC/ESRC Religion and Society Programme. For further details on the project see http://www.law.cf.ac.uk/clr/research/cohesion.html. We are also indebted to the members of the three religious tribunals who agreed to participate in the study and to those who attended our Workshop and Symposium at Cardiff Law School in the Spring of 2011 and to the anonymous referees whose comments have been very helpful in improving our general arguments. We are also thankful to Eithne D'Auria at the Centre for Law and Religion at Cardiff for her help in relation to Catholic Canon Law and to Amy Jackson at the University of Reading for her assistance in relation to theories of legal pluralism.

* Lecturer in Law, Cardiff University. Email: SandbergR@cf.ac.uk

*** Professor of Law, Cardiff University. Email: DouglasG@cf.ac.uk

*** Professor of Law and Director of the Centre for Law and Religion, Cardiff University. Email: Doe @cf.ac.uk

${ }^{* * * *}$ Senior Lecturer in the School of History, Archaeology and Religion and Director of the Centre for the Study of Islam in the UK, Cardiff University. Email: Gilliat-RayS@cf.ac.uk

****** Former Research Associate, Cardiff University.
} 


\section{INTRODUCTION}

Religious tribunals have operated in Britain for centuries. ${ }^{1}$ The Church Courts were the earliest courts that looked like courts of law. ${ }^{2}$ And even today, although their jurisdiction is now much trimmed, ${ }^{3}$ the modern ecclesiastical courts of the Church of England remain part of the English legal system; ${ }^{4}$ their decisions are subject to judicial review by the High Court. ${ }^{5}$ Moreover, leaving to one side the constitutional peculiarities of the established church, ${ }^{6}$ the English legal system has long accepted and administered multiple forms and sources of law. Historically, an equitable jurisdiction grew alongside the common law and today a single coherent hierarchy of sources exist whereby legal norms originating from the European Union, international human rights instruments and devolved institutions are included alongside the decisions of the common law courts and legislation enacted at Westminster. Yet, in the shadows of $9 / 11,{ }^{7}$ the existence of religious legal systems has proved contentious. A number of Western societies have seen heated debates about the extent to which religious legal systems are, and should be, accommodated within the national legal systems, and, in most cases, these debates have become debased into moral panics characterised by a fear of Shariah. ${ }^{8}$ In Canada in 2004 a report authored by the former

\footnotetext{
${ }^{1}$ We recognise that the terms 'religious tribunal' and 'religious court' are useful (but limited) labels to describe similar structures which have been set up by faith communities. We use the term 'court' or 'tribunal' in the functional senses identified by Roger Cotterrell, as going beyond 'dispute resolution' to embrace administrative processing and enforcement of norms through the application and development of legal doctrine: R Cotterrell, The Sociology of Law (Oxford University Press 1992) 208.

${ }^{2}$ S F C Milsom, Historical Foundations of the Common Law ( $2^{\text {nd }}$ edn. Butterworths, 1981) 25. A single judge considered and compared the evidence of witnesses and applied the rules of law to the facts. The rules of law could even be looked up in books.

${ }^{3}$ See R B Outhwaite, The Rise and Fall of the Ecclesiastical Courts, 1500-1860 (Cambridge University Press, 2006).

${ }^{4}$ N Doe, The Legal Framework of the Church of England: A Critical Study in a Comparative Context (Clarendon Press, 1996) chapter 5 and M Hill, Ecclesiastical Law ( $3^{\text {rd }}$ edn, Oxford University Press 2007) chapters 6 and 7.

${ }^{5}$ Ecclesiastical Jurisdiction Measure 1963, s81. See M Hill, 'Judicial Review of Ecclesiastical Courts' in N Doe, M Hill and R Ombres (eds) English Canon Law (University of Wales Press 1998) 104.

${ }^{6}$ See R Sandberg, Law and Religion (Cambridge University Press 2011) chapter 4.

${ }^{7}$ According to Bharma, it is vital that we bear in mind that we are all 'post-colonial and post-9/11 people': M K Bharma, The Challenges of Justice in Diverse Societies (Ashgate 2011) 112, 114.

${ }^{8}$ This spelling of the word 'Shariah' is used throughout this article since it is the spelling adopted by the Muslim Shariah Council we studied.
} 
Attorney General, Marion Boyd, stating that the 'Arbitration Act [1991] should continue to allow disputes to be arbitrated using religious law,, 9 led to riots in major Canadian cities and a statement by the Premier of Ontario, Dalton McGuinty, that, 'There will be no shariah law in Ontario. There will be no religious arbitration in Ontario. There will be one law for all Ontarians' ${ }^{10}$ And in London in 2008, a lecture by the Archbishop of Canterbury, Dr Rowan Williams, in which he suggested that 'we have to think a little harder about the role and rule of law in a plural society of overlapping identities' caused uproar. ${ }^{11}$

These two moral panics -concerning the existing accommodation of religious legal systems - point to a need to understand both the extent to which religious legal systems are already accommodated by the State's legal system and the extent to which they could be so accommodated. A leading work in this debate, cited by the Archbishop in his lecture, is Ayelet Shachar's book Multicultural Jurisdictions. ${ }^{12}$ Many commentators have followed the Archbishop in promoting Shachar's concept of 'transformative accommodation'. ${ }^{13}$ However, most of the time transformative accommodation is simply referenced: ${ }^{14}$ few commentators have recognised that Shachar herself was advocating 'transformative accommodation' as one

\footnotetext{
${ }^{9}$ M Boyd, Dispute Resolution in Family Law: Protecting Choice, Promoting Inclusion (Ministry of the Attorney General, 2004).

${ }^{10}$ L E Weinrib, 'Ontario's Sharia Law Debate: Law and Politics under the Charter' in R Moon (ed) Law and Religious Pluralism in Canada (UCB Press 2008) 239 at 250.

${ }^{11}$ R Williams, 'Civil and Religious Law in England - A Religious Perspective' (2008) 10 Ecclesiastical Law Journal 262. For an analysis of the media reaction to the Archbishop's lecture, see chapter 7 of N A Kabir, Young British Muslims (Edinburgh University Press 2010).

${ }^{12}$ A Shachar, Multicultural Jurisdictions: Cultural Differences and Women's Rights (Cambridge University Press 2001).

${ }^{13}$ The Archbishop defined 'transformative accommodation' as 'a scheme in which individuals retain the liberty to choose the jurisdiction under which they will seek to resolve certain carefully specified matters' : Williams, (n 11) 274.

${ }^{14}$ See, e.g., A Bradney, Law and Faith in a Sceptical Age (Routledge-Cavendish 2009) 51-52 and B Jackson, “"Transformative Accommodation" and Religious Law' (2009) 11 Ecclesiastical Law Journal 131-153.

Although a recent report funded by the British Academy cites the work of Shachar as part of its discussion of possible State responses to minority legal orders, the report refers only to transformative accommodation: $\mathrm{M}$ Malik, Minority Legal Orders in the UK (The British Academy, 2012) 36. In contrast to legal studies, some works in political science do engage with Shachar's wider arguments they do not do so from an empirical perspective. See, e.g., the essays collected in A Eisenberg and Spinner-Halev (eds), Minorities within Minorities: Equality, Rights and Diversity (Cambridge University Press, 2005).
} 
form of what she refers to as 'joint governance'. Although 'transformative accommodation' is Shachar's preferred form of joint governance, it is not the only form.

This article seeks to discuss the arguments and the various forms of joint governance put forward by Shachar in light of the findings of a recent multidisciplinary research project which sought to collect information on the role and practice of religious tribunals in England and Wales. ${ }^{15}$ Unlike previous studies which have focused upon only one religious tradition, ${ }^{16}$ our project examined the workings of three religious tribunals in detail: ${ }^{17}$ the Catholic National Tribunal for Wales, the London Beth Din and the Shariah Council of the Birmingham Central Mosque. ${ }^{18}$ This article uses this understanding of how these tribunals operate in practice in order to re-assess Shachar's theoretical arguments. We suggest that, although this juxtaposition provides support for Shachar's call for 'joint governance', transformative accommodation is less helpful than the other variants of joint governance that she proposed. Moreover, our empirical findings underscore several weaknesses inherent in Shachar's argument that need to be addressed.

\section{THE FOUNDATIONS OF JOINT GOVERNANCE}

Shachar's work, like our research project, begins from a legal pluralist perspective. Although, ironically, a plurality of ideas about legal pluralism can be said to exist, ${ }^{19}$ for our purposes

\footnotetext{
${ }^{15}$ For further discussion of our methodology and findings see G Douglas et al, 'Marriage and Divorce in Religious Courts: A Case Study' (2011) 41 Family Law 956-961 and G Douglas et al, 'The Role of Religious Tribunals in Regulating Marriage and Divorce' (2012) 24 (2) Child and Family Law Quarterly 139-157.

${ }^{16}$ For example, Shariah courts in particular have been the subject of valuable studies by S Shah-Kazemi, Untying the Knot: Muslim Women, Divorce and the Shariah (Nuffield Foundation 2001) and S Bano, 'Islamic Family Arbitration, Justice and Human Rights in Britain', (2007) 1 Law, Social Justice \& Global Development Journal http://www.go.warwick.ac.uk/elj/lgd/2007_1/bano (accessed 21 July 2011).

${ }^{17}$ Our study involved in depth interviews with personnel from all three tribunals, observation of 27 Shariah Council hearings and analysis of two years' worth of statistics relating to the Catholic Tribunal.

${ }_{18}$ Note, however, that since our empirical investigation consisted mainly of interviews with court personnel, the data collected therefore is from the perspective of the court rather than of the users.

${ }^{19}$ A number of different classifications exist (see Bharma (n 7) 93). Tamanaha, for instance, draws a distinction between colonial legal pluralism (epitomised by M B Hooker, Legal Pluralism: An Introduction to Colonial and Neo-Colonial Laws (Clarendon Press 1975)) and the more recent scholarship characterised by the suggestion that 'there are many 'legal' orders operative in society, of which State law is just one, and often not the most
} 
Tamanaha's understanding of legal pluralism can be adopted, that is, the acceptance that 'it is normal for more than one "legal" system to co-exist in the same social arena'. ${ }^{20}$ It requires the acceptance of what Eugen Ehrlich famously referred to as 'living law', the existence of rules 'based on social behaviour rather than the compulsive norms of the state', which are generated by formal and informal social groupings or 'social associations'. ${ }^{21}$ Shachar follows Cover's use of the Greek term 'nomos', ${ }^{22}$ to refer to minority communities that generate sets of group-sanctioned norms of behavior that differ from those encoded in state law'. ${ }^{23}$

Our empirical research shows how a number of religiously-based nomoi groups exist in twenty-first century Britain. Our study focused on the matrimonial jurisdiction of three such tribunals, namely: the Family Division of the Jewish London Beth Din, which is part of the United Synagogue, dealing with questions concerning Jewish status, conversion, divorce and arbitration; ${ }^{24}$ the Shariah Council of the Birmingham Central Mosque, which provides rulings, guidance and advice on a range of issues including matrimonial and inheritance issues as well as requests to learn more about Islam; and the Catholic National Tribunal for Wales in Cardiff, which serves as the equivalent of the 'diocesan' court for the three dioceses $^{25}$ in Wales ${ }^{26}$ and exercises the judicial powers laid out in the Code of Canon Law.

\footnotetext{
powerful one' (characterised by J Griffiths 'What is Legal Pluralism?' (1986) 24 Journal of Legal Pluralism 1): B Z Tamanaha, A General Jurisprudence of Law and Society (Oxford University Press 2001) 115-116. ${ }^{20}$ Ibid 171

${ }^{21}$ E Ehrlich, Fundamental Principles of the Sociology of Law (Transaction Publishers, 2002) 39.

${ }^{22}$ R M Cover, 'The Supreme Court 1982 Term, Forward: Nomos and Narrative' (1983) 97 Harvard Law Review 4.

${ }^{23}$ She defines nomoi groups as groups of people that share a comprehensive world view which extends to creating a law for the community': Shachar (n 12) 2, fn 5; citing A Greene 'Kiryas Joel and Two Mistakes about Equality'(1996) 96 Columbia Law Review 1, 4. The use of the term 'law' here has been criticised. Phillips argues that its use means that Shachar is restricting her focus to groups who 'are already staking extensive claims': A Phillips, Multiculturalism without Culture (Princeton University Press 2007) 19.

${ }^{24}$ It is over 100 years old. For discussion of how the Arbitration Act 1996 operates in relation to religious arbitrators, see Sandberg, (n 6) chapter 9.

${ }^{25}$ The term 'diocese' refers to the territories that are subject to the jurisdiction of Bishops. At the smallest level, dioceses are divided into parishes.

${ }^{26}$ Wales for this purpose includes part of Herefordshire.
} 
All three tribunals have been active for some time and remain busy, vibrant institutions which play an important role in the lives of some believers. The communities we studied embrace Shachar's notion of 'joint governance'; the people who use the tribunals 'jointly belong to more than one community, and will accordingly bear rights and obligations that derive from more than one source of legal authority'. ${ }^{27}$ Our research confirmed that the fundamental rationale for the grant of the religious annulment/divorce is to declare that the religious marriage is over and to enable the parties to remarry within the faith. For adherents, being able to remarry religiously serves both to enable them to remain within their faith community and to regularise their position with the religious authorities. This is particularly crucial in the Jewish religion, because the failure to obtain a get will jeopardise the legitimate status of the parties' future children and descendants. This is underlined by the following exchange with one of our interviewees at the Beth Din:

Q: Just to confirm: for a marriage that was conducted under Orthodox auspices, if that marriage is not then dissolved under Orthodox auspices is that tantamount to them losing their religion?

A: It's not losing their religion but, you see, it would mean that a subsequent relationship they would enter into, if they hadn't dissolved their marriage, would be adultery. So a woman who had not had her marriage dissolved according to Jewish law who then had had a civil divorce and then went ahead and married another person then that would be an adulterous relationship which, whilst they decide they may not take that seriously, we take it very seriously from our traditional Jewish teachings and off-spring of such a union would be regarded as seriously handicapped in terms of Jewish status law.

\footnotetext{
${ }^{27}$ Shachar (n 12) 13.
} 
Although the existence of religious tribunals is by no means a new phenomenon, this notion of belonging and deriving rights and obligations from a legal system other than the state has proved particularly controversial in recent years. However, as Shachar usefully points out, while for some secularists it is the very existence of religious tribunals that is problematic, ${ }^{28}$ for most critics the 'problem' with religious tribunals is what she refers to as the 'paradox of multicultural vulnerability' ${ }^{29}$ This refers to the fear that the 'accommodation of different cultures can conflict with the protection of certain members' citizenship rights'; $;^{30}$ the recognition of the rights and obligations that result from belonging to a nomoi group can paradoxically reduce the rights and obligations that a person would ordinarily enjoy by virtue of their citizenship. ${ }^{31}$ This may occur, for example, where the nomos of the group differs from that of the state as regards gender roles or sexual orientation. ${ }^{32}$ The paradox refers to the way in which 'the same policy that seems attractive when evaluated from an inter-group perspective can systematically work to the disadvantage of certain group members from an intra-group perspective' ${ }^{33}$

While it is important not to overplay the 'paradox of multicultural vulnerability', ${ }^{34}$ Shachar's identification of the paradox allows us to recognise that those who use the religious tribunals are both 'culture-bearers and rights-bearers' ${ }^{35}$ This mandates us to attempt a more ambitious and realistic solution than simply concluding that we should 'abandon any attempt

\footnotetext{
${ }^{28}$ The objection being that the tribunal poses a challenge to the law of the State: see, for instance, the 'One Law for All' campaign'. See D MacEoin, Sharia Law or 'One Law for All? (Civitas, The Cromwell Press Group 2009) http://www.civitas.org.uk/pdf/ShariaLawOrOneLawForAll.pdf (accessed 02 December 2011).

${ }^{29}$ Shachar (n 12) 3.

${ }^{30}$ Ibid 4.

31 Ibid 3.

${ }^{32}$ For a discussion of the tensions which have emerged between laws protecting religious freedom and those which prohibit discrimination on grounds of sexual orientation, see R Sandberg, 'The Right to Discriminate' (2011) 13 Ecclesiastical Law Journal 157.

${ }^{33}$ Shachar (n 12) 3. While inter-group equality is concerned with establishing equal treatment between cultural and religious intra-group inequalities is concerned with establishing equality within cultural and religious groups.

${ }^{34}$ See Phillips for the criticism of the tendency whereby 'principles of gender equality were being deployed as part of a demonization of minority cultural groups': Phillips (n 23) 2.

${ }^{35}$ A Shachar, 'Privatizing Diversity: A Cautionary Tale from Religious Arbitration in Family Law' (2008) 9 (2) Theoretical Inquiries in Law 573, 593.
} 
to enhance the autonomy of minority cultures'. ${ }^{36}$ As Shachar argues, the paradox raises 'a different and more complicated challenge':

We need to develop a conception of differentiated citizenship which is guided by an ambitiously innovative principle: one that strives for the reduction of injustice between groups, together with the enhancement of justice within them. ${ }^{37}$

Shachar is, by no means alone in making these arguments. Her work explicitly draws upon a number of multiculturalist theorists such as Will Kymlicka, ${ }^{38}$ Charles Taylor ${ }^{39}$ and Iris Young $^{40}$ who from the early 1990s onwards called for 'a fresher and more nuanced understanding of citizenship' under which group-based distinctiveness 'should now be recognized, respected, and even nourished by the contemporary state'. ${ }^{41}$ However, in our view, Shachar makes three important (and novel) contributions.

\section{A. The Multicultural Triad}

Shachar's first contribution is to remind us that there are 'three parties to the multicultural triad'. ${ }^{42}$ Although Shachar follows Kymlicka, Taylor and Young in arguing in favour of respecting group-based cultural differences, she makes an important step forward because:

The earliest proponents of multiculturalism too often forget the position of the citizeninsider, who simultaneously belongs to, and is affected by, both the group and the state authority. ${ }^{43}$

\footnotetext{
${ }^{36}$ Shachar cites B Barry, Culture and Equality (Harvard University Press 2001) as an example of this approach.

${ }^{37}$ Shachar (n 12) 4. Anne Phillips calls this the 'minority within minorities' argument because it draws attention to the ways that groups can oppress their own internal minorities: see Phillips (n 23) 12.

${ }^{38}$ Shachar draws in particular on Kymlicka's concept of 'differentiated citizenship rights': W Kymlicka, Multicultural Citizenship: A Liberal Theory of Minority Rights (Oxford University Press 1995) 26. Note, however, that in this publication at least, Kymlicka does not seek to explore institutional models. See Susan Moller Okin's famous critique of Kymlicka's liberal theory on minority rights in S M Okin 'Is Multiculturalism Bad for Women?' in S M Okin et al. (eds.) Is Multiculturalism Bad for Women? (Princeton University Press 1999), 7.

${ }^{39}$ See, in particular, his ground-breaking essay, C Taylor, 'The Politics of Recognition' in A Guttmann (ed) Multiculturalism: Examining the Politics of Recognition (Princeton University Press, 1994) 25.

${ }^{40}$ See, e.g., I Young, Justice and the Politics of Difference (Princeton University Press, 1990).

${ }^{41}$ Shachar (n 12) 22, citing Taylor, (n 39), 38.

${ }^{42}$ Shachar (n 12) 5.
} 
There are, of course, dangers implicit in this approach. The focus on the citizen-insider (in addition to the focus upon the group and the state) may be problematic if it translates into an acceptance of an individualism which downplays the role that affiliations and memberships continue to have. ${ }^{44}$ Furthermore, the focus on the citizen-insider may be disproportionate if attention is not also afforded to citizens of the state who are not members of a nomoi group. ${ }^{45}$ However, although these risks should not be dismissed lightly, it is important to note that Shachar is saying that the citizen-insider should be part of the focus; she is not saying that it should be the sole focus. Moreover, such a focus follows from the identification of the paradox of multicultural vulnerability: this paradox cannot be solved without considering the agency of those within nomoi groups. As Phillips forcefully points out, reference to minority cultures is now 'widely employed in a discourse that denies human agency'. ${ }^{46}$ It is not simply the case of understanding how the citizen-insider is affected by their joint membership of the group and the state, we need also to understand the actions, desires and intentions of citizen-insiders themselves. This was highlighted in our empirical study. All three tribunals stressed their voluntary nature: as one of our interviewees at the Shariah Council put it, 'ultimately the decision is theirs'. One interviewee at the Beth Din stated that 'it's consensual for our clients coming here' and added:

I think we're concerned not to discourage people from making use of our process. We recognise that people are citizens living in a free society. No one has to come to us in a sense and so we want to make our process as accessible and as least problematic as

\footnotetext{
${ }^{43}$ Ibid 6.

${ }^{44}$ See, for instance, the work of Franck who declares that we live in an 'age of individualism' (T M Franck, The Empowered Self: Law and Society in an Age of Individualism (Oxford University Press, 1999) which is criticised by Bharma (n 7) 49-52.

${ }_{45}$ As the European Court of Human Rights has repeatedly made clear, freedom of religion constitutes not only 'one of the most vital elements that go to make up the identity of believers and their conception of life' but 'is also a precious asset for atheists, agnostics, sceptics and the unconcerned' (emphasis added): Kokkinakis $v$ Greece (1994) 17 EHRR 397.

${ }^{46}$ See Phillips(n 23) 9.
} 
possible. If two Jewish people who wish to end their marriage choose not to go to the

Beth Din I can't do anything about it and I don't want to put obstacles in their way.

\section{B. The Nature of Multicultural Identity}

Shachar therefore seeks to recognise 'the complex and multi-layered nature of multicultural identity' ${ }^{47}$ She asserts that we cannot 'remain blind to the web of complex and overlapping affiliations which exist between these competing entities'. ${ }^{48}$ Shachar is, again, not alone in making this point. Taylor's notion of the 'politics of recognition' is based on the understanding that personal identity is 'negotiated through dialogue, partly overt, partly internal, with others ${ }^{49}$ while Zigmunt Bauman has gone further to suggest that we live in an age of 'Liquid Modernity ${ }^{, 50}$ where people can change their identity as and when they choose. ${ }^{51}$ Such sentiments are also found in the literature on cosmopolitanism, ${ }^{52}$ which is 'built on the multiplicities of allegiances that characterise any person'. ${ }^{53}$ However, whilst calls for cosmopolitanism have been criticised on the basis that the term 'conjures up too much the world of the global elite, the cultural tourist' and gives 'too little weight to local attachment', ${ }^{54}$ this notion of identity as something which is constantly being negotiated transforms the debate on the recognition of nomos. As Phillips puts it, this understanding sees that people are 'cultural beings' rather than being 'of a culture'. ${ }^{55}$

\footnotetext{
${ }^{47}$ Shachar (n 12) 15.

${ }^{48}$ Ibid 5. This point was developed by the Archbishop in his lecture which included a call for the recognition of 'multiple affiliations', by which he meant the recognition that people take 'membership in different but overlapping sets of social relationship': Williams (n 11) 269.

${ }^{49}$ Taylor (n 39).

${ }^{50}$ See, e.g., Z Bauman, Liquid Modernity (Polity Press 2000).

${ }^{51}$ Z Bauman , 'From Pilgrim to Tourist - Or a Short History of Identity' in S Hall and P Du Gay (eds) Questions of Cultural Identity (Sage 1996) 18-36.

${ }_{52}$ See, e.g., J Waldron, 'Minority Cultures and the Cosmopolitan Alternative' (1992) 25 University of Michigan Journal of Law Reform 751.

${ }^{53}$ Phillips(n 23) 68.

${ }^{54}$ Ibid 68.

${ }^{55}$ Ibid 52.
} 
Shachar therefore overcomes one of the criticisms which Phillips makes of the literature on multiculturalism: 'the tendency to represent individuals from minority or nonWestern groups as driven by their culture and compelled by cultural dictates to behave in particular ways'. ${ }^{56}$ This allows an important distinction to be drawn between 'understanding cultural pressures, but not assuming that culture dictates'. ${ }^{57}$ Such an approach also overcomes a further criticism made of the literature by Phillips, the way in which commentators 'have exaggerated not only the unity and solidity of cultures but the intractability of value conflicts as well' ${ }^{58}$ Shachar's understanding of identity leads her to state that 'a group's established traditions are more fluid than we sometimes acknowledge.' ${ }^{59}$ This supports Ferrari's description of religious law as a 'dynamic phenomenon' because 'religions (and religious laws) are born and die every day'. ${ }^{60}$ Religious law should be understood to include both the rules found in sacred texts and also the more practical rules developed by religious groups themselves. ${ }^{61}$ This was underscored in our study of the three religious tribunals. All three of the tribunals we studied were creating and negotiating rules in a flexible way. For instance, ${ }^{62}$ although this may not be typical of Shariah Councils, ${ }^{63}$ the Shariah Council we studied did not claim to represent any single school of thought and said that they based their 'verdicts' upon rulings derived from the four main schools of Sunni thought together with other sources from the Sunni tradition, as well as minority interpretations. As one interviewee put it, 'if the

\footnotetext{
${ }^{56}$ Ibid 8-9.

${ }^{57}$ Ibid 41

${ }^{58}$ Ibid 8.

${ }^{59}$ Shachar (n 12) 40.

${ }^{60}$ S Ferrari, 'Religious Law: A Discussion' in A Huxley, (ed), Religion, Law and Tradition: Comparative Studies in Religious Law (Routledge, London 2002) 155. This is shown by the concept of angrezi shariat developed by Pearl and Menski to describe the hybrid legal systems which have evolved amongst Diasporas in Britain. See W Menski and D Pearl Muslim Family Law (Sweet and Maxwell, London 1998). Similar ideas about legal hybridity can be found in Ballard's term of 'Desh Pardesh' which describes the 'adaptive strategy' and 'skilled cultural navigation' by South African diasporas: R Ballard, 'Introduction: The Emergence of Desh Pardesh' in R Ballard (ed) Desh Pardesh: The South African Presence in Britain (Hurst, London 1994) 1, 4-5, 29-31.

${ }^{61}$ Sandberg (n 6) 170.

${ }^{62}$ This is also true of the Beth Din, which will look to a range of opinions and rulings from other batei din in reaching its judgments but, as there is no hierarchy of tribunals, it is not bound by any prior ruling.

${ }^{63}$ See Shah-Kazemi (n 16) and Bano (n 16).
} 
parties do wish to be judged by a particular school of thought then they would realise in the very initial stages that they have come to the wrong place'. The interviewee was adamant that:

No decision should be made in absence of reality and context which is where things can go wrong ... if you take a decision that is in the books. We feel we cannot apply ... just from the texts so what we do look at [it and say] this is what the Quran says, this is what the Hadith says ${ }^{64}$

Even the National Tribunal, which is part of the Catholic Church's court structure, took a flexible and creative approach drawing on commentaries as well as the Code of Canon Law ${ }^{65}$ and regarding its own decisions and rulings from Rome as persuasive but not binding. ${ }^{66}$ Our empirical work clearly rebutted popular understandings of religious customs and laws which regard such norms as simply being ancient and fixed.

\section{The Rejection of Binary Solutions}

Shachar's inclusion of the citizen-insider, her focus upon human agency and her recognition of the dynamic nature of nomos, leads her to reject straightforward and tempting solutions to the 'paradox of multicultural vulnerability'. In her view, inactivity on the part of the state perpetuates the paradox of multicultural vulnerability. She writes that a stance of " "nonintervention" may effectively translate into immunizing wrongful behaviour by more

\footnotetext{
${ }^{64}$ One interviewee at the Shariah Council explained that this flexibility was an objective taken into account when recruiting personnel: 'I select a person who is not bound by this school of thought or that school of thought or that decision which have been taken by one authority, we strictly go on the basis and view our case on the basis of Quran and Sunna'. For further discussion of this modern phenomenon (Takayyar) of selecting the most appealing and appropriate doctrine from amongst the existing Islamic schools see I Yilmaz, 'Law as Chameleon: The Question of Incorporation of Muslim Personal Law into English Law' (2001) 21 Journal of Muslim Minority Affairs 297.

${ }^{65}$ Most notably Dignitas Connubi which expands on the Canons, provides a fuller explanation and brings common procedures together. Articles found in legal journals and opinions of eminent Canonists are also persuasive.

${ }^{66}$ However, Doe has argued that whilst theoretically there is no system of precedent in the Catholic courts, in practice some form of precedent system does exist: N Doe, 'Canonical Doctrines of Judicial Precedent: A comparative study' (1994) 54 The Jurist 205.
} 
powerful parties'. ${ }^{67}$ Turning a 'blind eye' to what occurs within religious tribunals relegates 'these religious traditions to the margins, labelled as unofficial, exotic, or even dangerous (unrecognized) law'. ${ }^{68}$ Our study underlined how this critique can be made of the way in which English law affords no recognition to religious divorces. ${ }^{69}$ As Shachar notes, this proves problematic where Muslim and Jewish women are stuck in a 'split status' position where they are 'legally divorced according to state law, though still married according to their faith'; she writes that this 'may leave these women prey to abuse by recalcitrant husbands who are well aware of the adverse effect this situation has on their wives, as they fall between the cracks of civil and religious jurisdictions' ${ }^{70}$ The need to determine the status of the religious marriage was stressed by one of our interviewees at the Shariah Council:

There have been cases where a woman was pregnant by a man she wasn't married to, so we have to resolve the case ... because that cannot be left to carry on like that because that would be living in sin. Islamically, it's far better to be divorced than committing adultery and so we have to make an effort to deal with it as soon as possible so that she can marry him.

Moreover, our empirical research pointed at a further related problem where religious marriages are not registered and consequently the parties are not married in the eyes of the state. This means that should the (religious) marriage get into difficulties then those parties have little redress under state law. Rather than being able to use both the courts of the state and the tribunals of the group, such people can only have recourse to the tribunals of the group. Our research suggests that this is a real problem in the Muslim community. The

\footnotetext{
${ }^{67}$ Shachar (n 35) 593. She writes that this laissez-faire stance 'reinforces the myth that left to their own devices, identity groups could exist as autonomous entities bearing little relation to the state'. This is a myth because 'the "walls" of identity groups are never absolutely sealed', nomoi groups are always reacting to the effects of state power, even when they claim to be most isolated from them: Shachar (n 12) 37, 40.

${ }^{68}$ Shachar (n 35), 593.

${ }^{69}$ For a further discussion of this point, see G Douglas et al, 'Accommodating Religious Divorce in the Secular State: A Case-Study Analysis' in M Maclean and J Eekelaar (eds) Families: Deviance, Diversity and the Law (Hart Publishing 2012) forthcoming.

${ }^{70}$ Shachar (n 35) 576.
} 
Shariah Council we studied deals with a significant number (over half in the 27 cases that we observed) of litigants who do not have a marriage recognised under English law. ${ }^{71}$ These examples underscore the dangers of a laissez-faire stance.

This requires the rejection of the 'unavoidable costs' argument argued by Chandran Kukathas, ${ }^{72}$ which Shachar writes claims that 'a genuinely tolerant state will rarely intervene in minority group affairs - even if that minority group systemically violates certain of its member's citizenship rights'. ${ }^{73}$ Such non-interference with internal group affairs is sometimes justified by an appeal to the 'right to exit' rationale which argues that the role of the state should be limited to ensuring that at-risk group members are able to leave if they do not like their group's practices. ${ }^{74}$ Like many scholars, ${ }^{75}$ Shachar argues that this 'right to exit offers no comprehensive approach at all' because it imposes 'the burden of solving conflict upon the individual' whilst 'relieving the state of any responsibility for the situation': ${ }^{76}$

The right to exit rationale forces an insider into a cruel choice of penalties: either accept all group practices - including those that violate your fundamental citizenship rights - or (somehow) leave. ${ }^{77}$

As Phillips puts it, the 'right to exit' alone is insufficient because 'voice matters as well as exit. The right to leave has to be complemented by the right to stay'. ${ }^{78}$ Moreover, as Shachar points out, this emphasis on the 'right to exit' is based on the premise that individuals cannot

\footnotetext{
${ }^{71}$ Other studies had presented similar figures: see Shah-Kazemi (n 16) and Bano, (n 16).

${ }^{72}$ See C Kukathas, 'Are There Any Cultural Rights?' (1992) 20 Political Theory 105, 133 and, in response, W Kymlicka, 'The Rights of Minority Cultures: A Reply to Kukathas' (1992) 20 Political Theory 140-146.

${ }^{73}$ Shachar (n 12) 12; see also 68-70.

${ }^{74}$ Shachar (n 12) 41. On which see the chapters by Reitman and Weinstock in Eisenberg and Spinner-Halev (n 14).

${ }^{75}$ Phillips, for example, denounces the 'right to exit' rationale as not attaching 'enough significance to cultural belonging': Phillips (n 23) 133. She writes that it is based on a 'constructivist account of culture and universalist account of human nature' (135). For a further critique of the 'exit theory' using applied normative legal theory see F Ahmed, 'Personal Autonomy and the Option of Religious Law' (2010) 24(2) International Journal of Law, Policy and the Family 222.

${ }^{76}$ Shachar (n 12) 41. As Levy points out, 'to have a culture whose exit is entirely costless ... is to have no culture at all’: J T Levy, The Multiculturalism of Fear (Oxford University Press 2000) 112.

${ }^{77}$ Shachar (n 12) 41.

${ }^{78}$ Phillips (n 23) 157.
} 
simultaneously be members of both the state and the group. ${ }^{79}$ It presumes that group members 'have relinquished the set of rights and protections granted to them by virtue of their citizenship'. ${ }^{80}$ This is not the case; one of our interviewees at the Beth Din commented that they recognised that 'people are citizens living in a free society'. Moreover:

We are British citizens and we abide by British law and anything that's done from a Jewish perspective is in addition to civil law.

The 'unavoidable costs' response is therefore fundamentally flawed because it is based on an oversimplified "either-or"- type understanding of legal authority which is not tailored to respect individuals' manifold identities'. ${ }^{81}$ Our research supports Shachar in arguing against such a 'binary' approach and demonstrating the need for a 'new approach to multicultural accommodation [which] must break away from the prevailing yet misleading "either your culture or your rights" ultimatum that underpins existing solutions'. ${ }^{82}$ For Shachar, such a new approach may be styled as being based upon 'joint governance'.

\section{THE VARIANTS OF JOINT GOVERNANCE}

Shachar's solution to the paradox of multicultural vulnerability takes the form of a compromise which she calls 'joint governance'. Joint governance seeks to overcome the problem of 'artificially compartmentalizing the relationship between the group and the state

\footnotetext{
${ }^{79}$ The 'right to exit' is similar to the application of the 'specific situation rule' in cases concerning Article 9 ECHR. For instance in $R$ (on the application of Begum) $v$ Headteacher and Governors of Denbigh High School [2006] UKHL 15, the majority of their Lordships held that there would not be an interference with religious freedom where 'a person has voluntarily accepted an employment or role which does not accommodate that practice or observance and there are other means open to the person to practise or observe his or her religion without undue hardship or inconvenience' (para 23). See Sandberg (n 6) chapter 5.

${ }^{80}$ Shachar (n 12) 41.

${ }^{81}$ Shachar (n 12) 12. A similar point is made by Büchler who calls for the '(de-)construction of binary oppositions' in the context of determining the family law applicable to an individual on the basis of their nationality': A Büchler, Islamic Law in Europe? (Ashgate 2011) 131.

${ }^{82}$ Shachar (n 12) 5. For a detailed criticism of how Shachar over-states the arguments of her opponents see S M Orkin, 'Multiculturalism and Feminism: No Simple Question, No Simple Answers' in Eisenberg and SpinnerHalev (n 14) 67.
} 
into a fixed inside-outside division [which] conceals the extent to which both are in fact interdependent' ${ }^{83}$ For Shachar,

Joint governance promises to foster ongoing interaction between different sources of authority, as a means of improving the situation of traditionally vulnerable insiders without forcing them to adhere to an either/or choice between their culture and their rights. $^{84}$

However, Shachar's account of joint governance is itself based on a paradox. On the one hand, she claims that joint governance focuses upon individual agency. She writes that joint governance 'opens up the possibility that our agency as members of a culture and our agency as citizens of a state may be mutually reinforcing, and that cultural accommodation may actually enable this mutual reinforcement' ${ }^{85}$ Yet, her account of joint governance focuses almost entirely on the relationship between the state and the group as two corporate entities. Tellingly, she states that joint governance seeks to 'open up a new separation of powers fostering ongoing interactions between different sources of authority' ${ }^{86}$ For Shachar, joint governance is 'composed of dialogue between different non-monopolist power centers' ${ }^{87}$ The focus remains on the institutional level rather than on the individual level. ${ }^{88}$ This means that joint governance as understood by Shachar still does not place enough emphasis upon agency.

For Shachar, the 'model of joint governance describes a repertoire of accommodation designs which can be combined and applied in creative ways according to different social

\footnotetext{
${ }^{83}$ Shachar (n 12) 40.

${ }^{84}$ Ibid 88 .

${ }^{85}$ Ibid 90 . She notes that, "Joint governance is based on a "cultural" understanding of institutions which holds that the action and agency of individuals, groups and states is situational, i.e. it varies in different institutions settings and to some extent is shaped by them': ibid 89 .

${ }^{86}$ Ibid 13.

${ }^{87}$ Ibid 13-14. It is 'a radically new architecture for dividing and sharing authority in the multicultural state, one which encourages a mode of governance composed of dialogue between different non-monopolist power centers, rather than an imposition by "all knowing" state or government officials': ibid 88 .

${ }^{88}$ As discussed below, this makes Shachar's schema less achievable. As Phillips notes, 'In contemporary Europe joint governance between the state and religious bodies is not a likely outcome': Phillips (n 23) 153.
} 
needs and arenas'. ${ }^{89}$ This section seeks to explore the first four 'variants' of joint governance, namely federal-style accommodation, temporal accommodation, consensual accommodation and contingent accommodation. The next section will then explore the fifth variant, transformative accommodation, which has attracted considerably more interest. This has been somewhat inevitable given that Shachar presents the first four variants as 'straw' arguments since she clearly favours and argues for transformative accommodation. This is unfortunate because, as she recognises, the fusion of the approaches can be fruitful.

Moreover, the first four variants are more concrete than transformative accommodation, especially if they are not presented in the narrow way in which Shachar seems to present them and if more emphasis is given to the agency of the citizen-insiders. All five variants, therefore, deserve a reappraisal in the light of the findings of our empirical research.

\section{A. Federal Style Accommodation}

The first variant of joint governance, federal-style accommodation, occurs 'where power is allocated between several sub-units and among different branches and levels of government'. ${ }^{90}$ This may include nomoi groups alongside other sub-units: such as in the Province of Quebec in Canada. However, federal-style accommodation can only occur where there is 'a territorial division of authority'. Under this variant, 'the nomoi group must be regionally centred'. ${ }^{91}$ This would seem to rule out its application in the UK in relation to nomoi groups since, although some Christian churches are organised regionally, nomoi groups are generally dispersed geographically. However, the development and deepening of

\footnotetext{
${ }^{89}$ Shachar (n 12) 7. She concedes that no 'mere legal formula, or even the best of institution's designs, can ever single-handedly resolve all the immensely complex philosophical problems and near-inexorable moral and ethical tensions that arise out of encounters between different cultural communities in shared political spaces': ibid, 7-8.

${ }^{90}$ Shachar (n 12) 92.

${ }^{91}$ Ibid 93.
} 
political devolution provides evidence of this variant of joint governance and shows a move away from centrality with different levels of governance now becoming the norm. ${ }^{92}$

\section{B. Temporal Accommodation}

The remaining four variants of joint governance are 'based on jurisdictional rather than territorial considerations' and are therefore more helpful. ${ }^{93}$ The second variant, temporal accommodation, is 'time bound and issue specific': it holds that 'certain life events crucial to the continuation of the group's collective identity (such as the creation of a family or the early education of children) should be governed by group tradition as the sole and definitive source of authority' and that 'outside of these crucial moments, individuals must turn to state law, ${ }^{94}$ It may be applied, for example, to hold that the early education of children is a matter for the nomoi group whilst the later education of children is a matter for the state. This seems, however, to re-introduce the criticised 'either/or' approach by simply determining when culture trumps citizen rights and vice versa. Although Shachar claims that it 'avoids the "either/or" trap' in that it recognises a division of authority, 'neither the state nor the group has full and exclusive jurisdiction', ${ }^{95}$ this is only true when one looks at the full life of the group member. Under the example used earlier, the group would have full and exclusive jurisdiction over a small child while the state would similarly have full authority over an older child. Furthermore, this model depends on a precise definition of time- and issue-based jurisdictional boundaries between the state and the group, ${ }^{96}$ which would be difficult to achieve. ${ }^{97}$ The model also does not seem to recognise the fluid nature of identities. Although

\footnotetext{
92 On which see, further, e.g. N Bamforth and P Leyland (eds) Public Law in a Multilayered Constitution (Oxford, Hart Publishing 2003).

${ }^{93}$ Shachar (n 12) 95.

${ }^{94}$ Ibid 97.

${ }^{95}$ Ibid 98.

${ }^{96}$ Ibid 97, fn 21.

${ }^{97}$ This is the main reason why Shachar concludes that 'this scheme is problematic'; temporal accommodation is 'inherently unstable from an institutional point of view': ibid 102.
} 
Shachar claims that the approach recognises that 'a group member's sense of affiliation can and will shift across time,${ }^{98}$ this model prescribes when this shift will take place and assumes that it is the same for all group members. ${ }^{99}$

However, although temporal accommodation suffers from a number of problems, it does provide a number of insights into how joint governance can operate. It reminds us that tensions between states and groups 'typically arise around significant life events, ${ }^{100}$ which have meanings for both authorities. This is true for the religious tribunals we studied: as we have noted, they were all primarily involved with questions of marital status. The Shariah Council and the National Tribunal were concerned predominantly with divorce whilst the Beth Din also focused on broader questions of Jewish status. Further, Shachar notes that temporal accommodation schemes "must also allow individuals sufficient "inside" knowledge of their culture, so that they can ... make a meaningful decision to follow a traditional way of life'. ${ }^{101}$ This suggests that education is part of the answer to the paradox of multicultural vulnerability. This means that, although a joint governance system based on temporal accommodation may provide a better starting point than one based on territory, it needs to be combined with other forms of joint governance and a more fluid understanding of the agency of citizen-insiders, which recognises that the timing when the sense of affiliation shifts will differ for different people.

\section{Consensual Accommodation}

Shachar's third variant of joint governance, consensual accommodation, functions 'to permit individuals with multiple affiliations to exercise choice and make their own determinations

\footnotetext{
${ }^{98}$ Ibid 97.

${ }^{99}$ For a discussion of the nature of identity and the proposal to recognise 'identity markers' see Bharma (n 7) chapter 8.

${ }^{100}$ Shachar (n 12) 99.

${ }^{101}$ Ibid 98.
} 
about which legal authority - the state or the group, for example - will have their jurisdiction over their personal affairs' ${ }^{102}$ This could easily be combined with temporal accommodation. Temporal accommodation could dictate when group authority can arise; individuals can then choose whether or not to invoke it. ${ }^{103}$ This variant has two strengths. First, our empirical investigation showed that this is how the religious tribunals themselves understand the way in which they function. None of the tribunals we studied has a 'legal status' in the sense of 'recognition' by the state. According to one interviewee at the Beth Din:

People in high places seem to think that we've got some sort of official status when we've got no status whatsoever; it's consensual for our clients coming here.

Rather, the Tribunals derive their authority from their religious affiliation, not from the state, and that authority extends only to those who choose to submit to them. As one interviewee at the Shariah Council commented:

Obviously some people may not decide to come to the Council thinking we're divorced anyway but others feel that they still have to resolve it in the eyes of God and they come [to] the Shariah Council.

In short, the tribunals operate a voluntary jurisdiction. ${ }^{104}$ It may, of course, be questioned to what extent being of a particular religion is voluntary in than many people are born into a religion and community pressure may be a significant factor in keeping people within nomoi groups. ${ }^{105}$ This raises issues concerning how that choice is made and what safeguards need to be in place regarding the nature of consent, which, as we will see, are not fully addressed by Shachar.

\footnotetext{
102 Ibid 103.

${ }^{103}$ For a critique of this focus upon choice, see, e.g., Ahmed ( $n$ 75) who concludes that 'the limited legal power of individuals to choose the law that applies to then is enough neither to remove other objections to the system nor to support the claim that the system enhances personal autonomy': ibid 239.

${ }^{104}$ However, in relation to marriage/divorce issues, concerned, they are not 'arbitrators'. Their authority to rule on the validity/termination of a marriage does not derive from the parties' agreement to submit their 'dispute' to them (indeed, there may be no dispute) in the same way as an arbitration clause in a contract (for which the Beth Din and some Shariah tribunals would also qualify to rule on civil disputes). See Sandberg (n 6) chapter 9.

${ }^{105}$ This is the main criticism of the 'right to exit' arguments discussed above.
} 
The second strength of this variant is that it seems to place more emphasis upon agency. However, oddly, Shachar describes consensual accommodation as requiring a 'onetime choice of [which] legal framework will govern the individual's relevant affairs from beginning to the end ${ }^{106}$ She then uses this to attack this variant of joint governance deeming it 'misleading to assume that simply providing a one-time (and forever binding) legal opportunity to express consent will overcome the problem of in-group power relations'. ${ }^{107}$ This is true but there is no need to define consensual accommodation as requiring a 'one-time choice'. Given that identities are not fixed but are rather constantly renegotiated, it surely follows on from this that people can move between systems of authority. People may choose to be married under the authority of the group but divorced under the authority of the state. The 'one-time choice' idea is convenient since it avoids the question of how the moving from authority to authority is to be facilitated but it also brings us back to an 'either-or' understanding of religious identity. The advantage of consensual accommodation is that 'it delegates the decision of which facet of identity to emphasize in a given arena to the individual herself ${ }^{108}$ This is lost if that decision is a one-time choice. The ability to change one's mind is fundamental given that 'freedom of religion protects the subjective belief of an individual'. 109

However, the main challenge posed by this variant is determining whether or not there has been valid consent. ${ }^{110}$ As Shachar rightly observes, 'consensual accommodation must still provide an institutional setting that can ensure that vulnerable group members will have the

\footnotetext{
${ }^{106}$ Shachar (n 12) 103.

${ }^{107}$ Ibid 107.

${ }^{108}$ Ibid 104.

${ }^{109} R$ v Secretary of State for Education and Employment and others, ex parte Williamson [2005] UKHL 15, per Lord Nicholls at para 22.

${ }^{110}$ As Phillips observes, although it is the case that 'wherever there are groups, there is always the potential for coercion', 'it is important to recognise the choices people make, not read these as a reflection of their so-called culture or treat them as a false consciousness': Phillips (n 23) 176, 41.
} 
resources to choose'. ${ }^{111}$ In short, the group member must have the capacity to choose. This not only requires that there is sufficient information and education; ${ }^{112}$ it also requires action where the group member is deemed incapable of making that choice because they are too young, are under duress or are suffering from a mental illness. Although this poses difficult questions, ${ }^{113}$ guidance may be derived from the nuanced understanding of consent that has already been developed in English criminal law. For instance, ${ }^{114}$ according to section 74 of the Sexual Offences Act 2003, 'A person consents if he agrees by choice, and has the freedom and capacity to make that choice'. As Phillips points out, there is 'no answer that can catch all instances of coercion', meaning that 'we have to go primarily by what people say ${ }^{115}$ and there need to be measures that make it easier to get their voices (not someone else's) heard'. ${ }^{116}$ This question of determining whether or not there was consent requires cooperation between groups and the state, which may well blossom into a real partnership of joint governance including the citizen-insider. ${ }^{117}$ One way of maximising the chance of hearing the voice of the citizen-insider is to require the physical presence of representatives from both the state and the nomoi group. There are existing examples of such cooperation occurring: for instance, in the mandatory presence of a registrar at a religious wedding ceremony. ${ }^{118}$ It follows that, although there remains much to be thought through, consensual

\footnotetext{
${ }^{111}$ Shachar (n 12) 105.

${ }^{112}$ Ibid 108. See further, Barry (n 36) 239-40.

${ }^{113}$ As Shachar observes, 'the issue of consent becomes more complex when we think of children who are too young to express their jurisdictional preferences': Shachar (n 12) 106.

${ }^{114}$ The law relating to non-fatal and sexual offences provides two further insights. First, English criminal law recognises that there are some things to which people cannot legally consent. This is the case in relation to the main offences under the Offences against the Person Act 1861 but exceptions to this rule are granted as a matter of social policy (see $R v$ Brown [1993] 2 All ER 75). Second, the law on sexual offences recognises that there are certain situations where it can be presumed that there was no consent (see sections 75 and 76 of the Sexual Offences Act 2003)

${ }_{115}$ Phillips (n 23) 177.

${ }^{116}$ For Phillips, this would involve practical and specific measures which would remove obstacles, provide support services and otherwise assist people in making their personal decisions. See ibid 178.

${ }^{117}$ This is implicit in Shachar's insistence that 'consensual accommodation does not reserve for the group (or the state) the ultimate power to determine whether a person is "inside" or "outside" the nomoi community': Shachar (n 12) 107.

${ }^{118}$ Marriage Act 1949, s 53.
} 
accommodation offers a valuable potential step forward, which builds upon temporal accommodation.

\section{Contingent Accommodation}

Shachar's fourth variant, contingent accommodation, occurs where:

The state yields jurisdictional autonomy to nomoi groups in certain well-defined legal arenas, but only so long as their exercise of this autonomy meets certain minimal state-defined standards. If a group fails to meet these minimal standards, the state may intervene in the group's affairs and override its jurisdiction by applying the state's residual powers. ${ }^{119}$

English law already provides some examples of contingent accommodation. This is most clearly the case under the Arbitration Act 1996 whereby individuals are free to choose to have their civil ${ }^{120}$ disputes arbitrated by religious personnel which will be recognised and enforced by the civil courts unless there is a 'public policy which requires the court not to'. ${ }^{121}$ More generally, as Lord Hope observed in the Supreme Court in $R$ (on the application of E) $v$ JFS Governing Body, ${ }^{122}$ although 'it has long been understood that it is not the business of the courts to intervene in matters of religion', ${ }^{123}$ it 'is just as well understood, however, that the divide is crossed when the parties to the dispute have deliberately left the sphere of

\footnotetext{
${ }^{119}$ Shachar (n 12) 109.

${ }^{120}$ Under Arbitration Act 1996 s 82, ‘legal proceedings' means civil proceedings

${ }^{121}$ Arbitration Act $1996 \mathrm{~s} 1$. Kohn $v$ Wagschal and Ors [2007] EWCA Civ 1022 para 18. The Act further lays out the general duties of the arbitrator which must be adhered to: See Arbitration Act 1996 s5, 33 and 68. For an example of a court declining to uphold an arbitration award, see Soleimany v Soleimany[1999] QB 785. In Jivraj $v$ Hashwani [2011] UKSC 40, the Supreme Court confirmed that the law prohibiting discrimination on grounds of religion or belief in relation to employment does not apply to the selection, engagement or appointment of arbitrators and, if it did, it is likely that the genuine occupational requirement could be relied upon. 122 [2009] UKSC 15.

${ }^{123}$ Para 157. This may be styled the principle of non-justiciability (it has also been referred to as the doctrine of judicial abstention and the non-interference principle). See, further, the decisions in Mohinder Singh Kharira $v$ Daljit Singh Shergill [2012] EWCA Civ 983, His Holiness Sant Baba Jeet Singh Maharaj v Singh [2010] EWHC (QB) 1294 and Blake v Associated Newspapers [2003] EWHC 1960 and, the discussion by Sandberg (n 6) 74-76.
} 
matters spiritual over which the religious body has exclusive jurisdiction and engaged in matters that are regulated by the civil courts. ${ }^{124}$

As Shachar correctly observes, the contingent accommodation model 'may create far reaching review powers for the state'. ${ }^{125}$ However, again she downplays the usefulness of this variant. In particular, she takes a pessimistic view stating that 'this accommodation system also requires a complex regulatory regime because information must be gathered (presumably by the state authorities)' ${ }^{126}$ There is no reason, however, why the regulatory regime must be complex. It could well be the case that a clear demarcation of powers would suffice. Our research indicated that all three tribunals were keen to work within the state's legal framework. The general impression given was one of deference towards the state. One interviewee at the Beth Din said that they were 'very sensitive' and 'always err on the side of caution' to ensure that they did not apply something which 'could be seen as tantamount to impacting or impeding or obstructing civil law'. Similarly, an interviewee at the Shariah Council stressed that:

We work within the law of the land we cannot go against the law of the land and we say that and that actually would be going against Islam as well because we have to honour our contracts according to the Islamic teaching.

This deference was shown in the way in which all three tribunals strongly encourage the parties to obtain a civil divorce, if applicable, before they engage in the religious proceedings. As an interviewee at the Catholic Tribunal told us:

In Britain we cannot start, we cannot give an annulment without the people being divorced otherwise we're in trouble with the state, people sometimes forget that we, if

\footnotetext{
${ }^{124}$ Para 158. This may be styled the Forbes $v$ Eden exception (after the leading case: Forbes $v$ Eden (1867) LR 1 Sc \& Div 568), This exception means that courts will intervene in rare cases to enforce the laws of a religious group where there is a financial interest and in relation to the disposal and administration of property. In doing so, courts will adjudicate on and recognise religious law. See Sandberg (n 6) 76-77.

${ }^{125}$ Shachar (n 12) 110.

${ }^{126}$ Ibid 110.
} 
we try to dissolve something that the state hadn't dissolved then we would be in trouble.

The same view is taken at the Shariah Council:

In cases where women are already going through the civil courts and they are sort of in the middle of that, if they come to the Shariah Council and they say that they want to have the divorce we usually say to them that "once that's gone ahead". Because if we go ahead and say "you're divorced", they're still married under the legal system, which will create a conflict and Islam doesn't want you to have that conflict of status. You know what are going to write? Are you married or divorced? So in order to not cause any conflict in the person's own mind and also in terms of the state system its best for us to say to them "once that's resolved then come back to us" Moreover, the tribunal staff stated that they advised people to make use of civil law mechanisms and remedies. As one of our interviewees at the Beth Din put it:

We will want to make sure that people have gone through a proper process.... We will try and often send them to professionals. As far as civil law is concerned we will not give any advice, we will tell them that they need a civil divorce and we will often point them to a lawyer.

The Shariah Council stressed how it always advised women to register their marriage under state law. This suggests that where there is a clear demarcation of powers then this will be adhered to and even promoted by the tribunals. At the moment, the tribunals define their competence negatively by refusing to act where the state is competent and by promoting state law mechanisms which they are aware of. The Shariah Council, in particular, were very aware that many of the women who come to them were missing out on their rights under state law due to a lack of knowledge and understanding. This could be reduced through increased 
information transfer between the state and nomoi groups. Again, education appears to be the key.

Alternatively, if a more formalised scheme was considered desirable, it is possible to conceive of a system based on registration and regular inspections, which could be developed. ${ }^{127}$ Inspiration for such an endeavour may be found in existing models which are already in use. These include several voluntary registration systems which provide certain tangible and desirable benefits for registrants, ${ }^{128}$ as well as the model already in use in relation to schools with a religious character where the state continues to 'intervene' to ensure that certain standards are met, ${ }^{129}$ even in the case of independent faith schools where state has no financial interest in doing so. ${ }^{130}$ However, before adopting such a model thought needs to be given the tendency within certain religious communities not to make use of the registration systems that are already provided under English law. Our study seems to suggest that lack of education and knowledge is in part responsible for this but there is a need to ensure that the advantages accrued by the group and by the citizen-insider by dint of registration are real and meaningful, as well as ensuring that these advantages are clearly communicated.

It is clear that contingent accommodation poses a number of challenges, especially if the fluid nature of identity and belonging is to be recognised. There is a need to negotiate and re-negotiate a regulatory partnership between the group and the state. ${ }^{131}$ Shachar is correct to point to 'the inevitable power asymmetries between the state and the group' ${ }^{132}$ As

\footnotetext{
${ }^{127}$ For a discussion of registration systems pertaining to religious groups which already exist in European States see N Doe, Law and Religion in Europe (Oxford University Press 2011) chapter 4.

${ }^{128}$ Precedents here can be found in existing facilitative legislation which allows religious groups to register their buildings as places of public religious worship (Places of Worship Registration Act 1855) and places for the solemnisation of marriage (Marriage Act 1949 S4).

${ }^{129}$ See Sandberg (n 6) chapter 8.

${ }^{130}$ See the Education (Independent School Standards) (England) Regulations 2010.

${ }^{131}$ Shachar makes this point but yet again paints it in a necessarily confrontational light saying that thought should be given to 'when precisely responsibility must be reversed': Shachar (n 12) 112.

${ }^{132}$ Ibid 112 .
} 
Phillips has argued, it is important that the dialogue is not 'top-down'. ${ }^{133}$ This is why the focus ought to be on the rights of the citizen-insider. The clear demarcation of powers needs to be clearly communicated to the citizen-insider through a three-fold dialogue requiring the cooperation of both the state and the nomoi group.

The main problem with contingent accommodation is that the model focuses on methodology not principle. It is not clear what the guiding principle is. It could well be the case that the guiding principle could be derived from the consensual model: it could be that 'powers will be allocated between the state and the group in a way which maximizes these members' interests'. ${ }^{134}$ A similar approach is already found in the Children Act 1989 which is based on the guiding principle that the welfare of the child is paramount. ${ }^{135}$ Such an approach would overcome the "minimal standards" problem identified by Shachar, (that is, who is allowed to define them and how is one supposed to enforce them in a way consistent with the accommodation of deep cultural differences?' $),{ }^{136}$ by ensuring that the standards themselves are developed (and re-developed) through a on-going dialogue between the citizen-insiders, other representatives of the group and the state, rather than the state simply 'imposing' the standards found in its law. This would require the visible cooperation of the nomoi group and the state in dialogue with the citizen-insider. An approach that fuses and develops Shachar's second, third and fourth variants would provide a real system of 'joint' governance which is shared three ways to give both group and state a role to negotiate whilst primarily investing power in the citizen-insider.

\footnotetext{
${ }^{133}$ She notes that despite the obvious advantages of dialogue, in practice it 'has tended to encourage the sedimentation of cultural groups and communities and the selection of specific spokes people (generally male) who are then in a position to present their own readings of culture or community as if they were generally agreed upon': Phillips (n 23) 161.

${ }^{134}$ Shachar (n 12) 113.

${ }^{135}$ And indeed, the Arbitration Act 1996, which is based on the guiding principle that the arbitration must not offend public policy.

${ }^{136}$ Shachar (n 12) 116. It would also overcome the fear that the focus on 'minimal standards' will lead to a race to the bottom in terms of standards.
} 


\section{TRANSFORMATIVE ACCOMMODATION: A RED HERRING?}

In our analysis, the variants of joint governance already outlined can be fused and developed to point to a concrete way forward. However, for Shachar, although all of these variants 'represent a distinct evolution in the development of multicultural theory and practice', their 'strategies and solutions, while still provisional, point to the possibility of still another variant of joint governance whose success has yet to be tested'. ${ }^{137}$ This is her fifth, and favoured, variant of joint governance, the frequently cited 'transformative accommodation', which she suggests represents 'the most optimistically practical variant of joint governance'. ${ }^{138}$ Shachar writes that this fifth variant is transformative 'because it is designed to encourage group authorities themselves to reduce discriminatory internal restrictions' ${ }^{\prime}{ }^{139}$

Instead of viewing their conflict of interests as a problem, [transformative accommodation] considers it as an occasion for encouraging each entity to become more responsive to all its constituents. Through an arrangement of non-exclusive competition for the loyalties of those citizens who overlap both jurisdictions, transformative accommodation seeks to adapt the power structures of both nomoi groups and state in order to accommodate their most vulnerable constituents. ${ }^{140}$

On the face of it, this seems to be a general description of joint governance rather than the identification of a new variant. ${ }^{141}$ Moreover, it may be noted that, once again, Shachar's assumptions take a very 'top-down' approach, focussing on the group and the state and not

\footnotetext{
${ }^{137}$ Shachar (n 12) 113.

${ }^{138}$ Shachar claims that: 'This approach aims to enhance the jurisdiction of nomoi groups over matters crucial to their self-definition, and to ameliorate the disproportionate injury that certain categories of group members can suffer at the hands of their own cultures'. However, surely this can be said to be the purpose of joint governance in general (once the 'paradox of multicultural vulnerability' is recognised)? Ibid 14.

${ }^{139}$ Ibid 14.

${ }^{140}$ Ibid 117.

${ }^{141}$ The same is true of the first three of her four key assumptions unpinning transformative accommodation: ibid188. As Shachar concedes it is possible to 'observe such positive dynamics at work in other examples of joint governance', especially contingent accommodation: 117 . The difference between transformative accommodation and the other forms of joint governance is dealt with by Shachar, ibid 126-128.
} 
the citizen-insider, and this is despite the fact that she critiques other multicultural thinkers for doing just that.

Further, as Phillips points out, 'Shachar combines a strong sense of the distinctiveness and uniqueness of different religio-cultural traditions with a rational actor view of the world'; much of Shachar's exposition of transformative accommodation is 'written in the language of the marketplace'. ${ }^{142}$ This is particularly true of Shachar's fourth assumption upon which transformative accommodation is based. She writes that it is assumed that 'it is in the selfprofessed interest of the group and the state to vie for the support of their constituents'. ${ }^{143}$ This suggests that Shachar sees transformative accommodation as a competitive model. Indeed, she observes that, 'each entity must "bid" for these individuals' continued adherence to its sphere of authority'. ${ }^{144}$ This reference to competition is unnecessary: consensual accommodation should lead to collaboration between the group and the state, not a battle between them. Both parties have much to gain, especially given the neo-liberal rolling back of the state; ${ }^{145}$ the operation of nomoi groups can be seen as providing an illustration of David Cameron's 'big society' in practice.

\section{A. The Three Core Principles of Transformative Accommodation}

Shachar claims that transformative accommodation is characterised by having 'three core principles'. ${ }^{146}$ It is questionable, however, whether these core principles actually advance matters. Rather, they seem to regurgitate features found in the other variants of joint governance often in rather unhelpful ways.

\footnotetext{
${ }^{142}$ Phillips (n 23) 153.

143 Shachar (n 12) 118.

144 Ibid 117.

${ }^{145}$ A point considered in A Shachar. 'State, Religion and The Family: The New Dilemmas of Multicultural Accommodation' in R Ahdar and N Aroney (eds) Shari'a in the West (Oxford University Press 2010) 115-134.

${ }^{146}$ She writes that: 'These principles define how authority can be usefully divided, how transformative accommodation can maintain the separation of powers, and most importantly, how members of groups can exercise some agency once jurisdiction has been shared': Shachar (n 12) 118-119.
} 
The first principle, the 'sub-matter' allocation of authority, 'observes that contested social arenas (such as education, family law, criminal justice, immigration, resource development, and environmental protection) are internally divisible into "sub-matters": multiple, separable, yet complementary legal components'. ${ }^{147}$ Transformative accommodation allocates 'jurisdictional authority upon sub-matter lines' and this division into sub-matters ensures that 'only when they are addressed [by both state and group] together can any legal dispute in a given social arena be resolved. ${ }^{, 148}$ Shachar gives the example of family law matters. ${ }^{149}$ She identifies a distinction between the 'demarcating' function, the role of family law in 'defining and regulating a group's membership boundaries', ${ }^{150}$ and the 'distributive' function, 'which shapes and allocates rights, duties, and ultimately powers between men and women within the group'. ${ }^{151}$ She notes that divorce proceedings generally involve both of these aspects, 'a change in personal status (the demarcating function) and a determination of property relations between the spouses (the distributive function)'. ${ }^{152}$ Under her schema, the division of these functions between group and state means that both are forced into a dialogue. However, our empirical work shows that this does not appear to be the case. It was striking that the religious tribunals we studied are mostly exercising a demarcating function. In all three tribunals, the fundamental rationale for the grant of the religious annulment/divorce is to enable the parties to remarry within the faith. The focus is on the marriage itself, not the ancillaries (children, money and property). ${ }^{153}$ The tribunals are ultimately concerned with religious status. In doing this, they

\footnotetext{
${ }^{147}$ Shachar (n 12) 119.

${ }^{148}$ Ibid 119.

${ }^{149}$ Ibid 119-120.

${ }^{150}$ Ibid 51

${ }^{151}$ Ibid 50-51, 54-55.

${ }^{152}$ Ibid 51.

${ }^{153}$ The basis for the ending of the marriage varies as between the three tribunals. It could be said that the Shariah Council has a view of the process closest to the basis of current English divorce law as both focus on whether the marriage has 'irretrievably broken down'. In terms of its marital jurisdiction, the role of the Council is adversarial: it must be satisfied there are valid grounds for declaring the marriage over, based on
} 
have little contact or dialogue with the state which is responsible for the distributive functions. The current implicit and blunt 'sub-matter' allocation of authority does not seem to provide an incentive for dialogue between group and state.

Shachar's second principle, the "no monopoly" rule, draws from the separation of powers. ${ }^{154}$ This rule states that 'neither the group nor the state can ever acquire exclusive control over a contested social arena that affects individuals both as group members and as citizens'. ${ }^{155}$ It 're-defines the relationship between the state and its minority groups by structurally positioning them as complementary power-holders'. ${ }^{156}$ Although this seems to be little more than an elucidation of the concept of joint governance as understood above, Shachar seems to suggest that this rule would lead to the blurring of jurisdictional boundaries. She observes that, 'Thanks to this interdependent balance, decision-makers in contested social arenas can benefit from a broader pool of precedent and autonomy'. ${ }^{157}$ This would seem to be unrealistic and undesirable given that the laws of the state and nomoi groups have different focuses. ${ }^{158}$ The religious tribunals in our study were all aware that they did not exercise a legal monopoly. As we have noted above, the limits to their jurisdiction were shaped by their understandings of state law and the overriding impression given was one of

evidence submitted by the applicant and in light of any conflicting evidence from other spouse. In contrast, for the Beth Din, no grounds need be proved, and there is no 'ruling' or judgment that the marriage has broken down. Its role is supervisory: to ensure the parties divorce each other correctly and that the get document itself is properly drawn up. In terms of its divorce jurisdiction, the National Tribunal's role is inquisitorial: the Tribunal must satisfy itself that there are grounds to annul the marriage. In essence, the Tribunal is concerned with whether there was a true consent between the parties at the time of the marriage. See, further, G Douglas et al (n1 and $\mathrm{n} 15)$.

${ }_{154}$ 'Like other separation-of-powers models, transformative accommodation intentionally eschews the idea of exclusive or absolute authority': Shachar (n 12)) 119.

${ }^{155}$ Ibid 121.

${ }^{156}$ Ibid.

157 Ibid.

${ }^{158}$ See Doe's discussion of the 'facility' and the 'order' functions of Christian laws: Doe (n 4) 33-47 and N Doe, 'Modern Church Law' in J Witte Jr and F S Alexander (eds) Christianity and Law (Cambridge University Press 2008) 271. 
deference. Moreover, the interviewees were keen to stress the religious nature of their work.

As one interviewee at the Catholic Tribunal put it, 'the whole process is pastoral'. ${ }^{159}$

The third principle, 'the establishment of clearly delineated choice options', refers to the need to establish 'clearly delineated choice options through which constituents can express approval or disapproval of state or group decisions'. ${ }^{160}$ This seems to amount to little more than the notion of consensual accommodation as developed above (rejecting Shachar's insistence that consent is a one off choice). ${ }^{161}$ However, rather than focusing on the nature of consent, Shachar focuses upon when people can choose to move from group to state (or vice versa). She writes that 'such participation must proceed on an issue-by-issue basis, once the initial jurisdictional boundaries have been set, thus allowing nomoi members to meaningfully choose between jurisdictions'. ${ }^{162}$ However, these 'reversal provisions' are not to be taken lightly:

The purpose is not to fracture group solidarity so that members can opt out at the slightest opportunity. The initial division of authority between group and state must remain meaningful and presumptively binding on its individual. ${ }^{163}$

This would seem to amount to a presumption that people should remain subject to the authority which they originally found themselves in. Moreover, Shachar seems to be saying

\footnotetext{
${ }^{159}$ In response to a question asking what the necessary personal qualities needed for him to fulfil his job was, he stated that it was: 'an ability to blend the two concepts of the judicial and the pastoral because it is an important role within the Church but one has to remember that one cannot, as a religious minister, it's really swimming against the tide by being a purely judicial figure. We can't simply make religion into a system of laws and rules and regulations, Christ himself was very clear about that and he criticised the Pharisees and the Scribes and the lawyers of his day for doing that. So what one doesn't want to do is to fall into the trap of becoming locked in a legal mindset, you have to have a legal mindset or the ability to adapt to working within judicial structures and disciplines but at the same time you have to retain a pastoral sensitivity and remember that you are also, in your role as a church lawyer, you are trying to help people and you are trying to help people to re-build their lives spiritually speaking and also emotionally and socially after the trauma of the breakdown of a marriage'. relationship so it requires a certain ability to blend those two skills and to remember that you are a lawyer but you are still a priest and a priest first and foremost.'

${ }_{160}$ Shachar (n 12) 121.

${ }^{161}$ See Shachar (n 12) 127.

162 "Where most accommodation models only allow membership to be "entirely in" or "entirely out", the possibility to "opt in" or "opt out" of specific group positions produces a decisive shift in group influence from dominant power-holders to individual members': ibid 123.

163 Ibid.
} 
that these clear reversal points would become fixed. ${ }^{164}$ Shachar uncharacteristically assumes a static understanding of the interaction between groups and the state and assumes that the citizen-insider is unable to fend for themselves. ${ }^{165}$ This is inconsistent with the acceptance of the fluid nature of identities and could well exacerbate the 'paradox of multicultural vulnerability'. At the very least, it is difficult to see how this proposal advances matters.

\section{B. Five Problems with Transformative Accommodation}

In short, we contend that a fusion of the earlier variants of joint governance may provide a preferable solution to the paradox of multicultural vulnerability than the much cited variant of transformative accommodation. However, that is not to say Shachar's elucidation of transformative accommodation does not provide any further insights which can be added to those developed from the earlier variants of joint governance. Many of the innovations which she attributes to transformative accommodation can already be found in embryonic form in the other variants. Moreover, there are many specific points which are not contentious. For instance, she writes that there is a need for members to be 'granted at least minimal (education or material) resources through the state's exercise of authority in its designated sub-matter'. ${ }^{166}$ We agree. This seems to be a rare recognition on Shachar's part that it cannot be assumed that the state and the group have the same responsibilities and roles. It is only right that it would be the role of the state to ensure that information is available. However, generally, it seems that the mention of transformative accommodation confuses rather than aids the debate. Our empirical work points to five further problems with the account given by Shachar.

\footnotetext{
${ }^{164}$ Shachar contends that the predefinition of reversal points 'relieves the vulnerable insider from the need to negotiate individually the transition between group and state norms on a case-by-case basis': ibid 125 .

${ }^{165}$ This seems unrealistic. It would be impossible to foresee all eventualities. It is likely to be the case that new and distinguishing facts would arise.

${ }^{166}$ Shachar (n 12) 124.
} 
First, Shachar's account presumes that the dialogue and choice is simply between the group and the state. In addition to overlooking the fact that neither the group nor the state is a homogeneous entity, this ignores how having multiple affiliations means that people are often members of more than one group. There are often groups within larger groups. And movement between these groups is possible. This was shown clearly in the phenomenon of 'forum shopping' we observed in the religious tribunals we studied. The absence of an appeal hierarchy in the Muslim and Jewish communities means that litigants can, to some extent, choose which tribunal they go to according to the way in which (they think) the law will be applied to them and can then make use of a different religious tribunal if they are not satisfied the first time. ${ }^{167}$ This means that Shachar's implicit assumption that there is only one group in play at one time is misguided.

Second, Shachar's account assumes the presence of conflict between the group and the state and employs a too legalistic understanding of authority. She writes that 'transformative accommodation shares with federal-style accommodation the assumption that although group leaders may want to hold complete power over all group members, they can be convinced of the practical advantages of compromise when faced with the alternative of receiving no public legal authority at all'. ${ }^{168}$ This would seem to be a false assumption. The informants at the religious tribunals in our study did not seem to want to hold 'complete power' and they also did not seem to mind whether they had any 'public legal authority'. Moreover, the authority which group leaders enjoy is not purely 'legal'; rather it seemed to derive from a combination of their position in the court, their standing in the community and

\footnotetext{
${ }^{167}$ This forum shopping is accepted by the Shariah Council we studied. They told us how other Councils may come back to the original Council to verify any evidence and the Council's original decisions. When we asked one of our interviewees at the Shariah Council whether this forum shopping concerned them, their response was as follows: 'It doesn't cause problems for me because ultimately the decision is theirs, which is what I say to them, it's up to yourself. ... If they can choose to go with what this mosque is saying and if a mistake has been made then the sin would be on the members who have made that decision with that information.'

${ }^{168}$ Shachar (n 12) 126.
} 
their own personality. ${ }^{169}$ The majority of these people are also religious leaders and their 'legal' functions are just one part of their much larger pastoral role. This is shown by the work of the Dayanim at the Beth Din who spend a significant amount of time answering questions by Rabbis and lay people relating to matters concerning daily ritual and practice. As one interviewee commented:

First and foremost [the Dayanim] are a resource both for Rabbis in our synagogues who aren't as learned as they are and for laymen to come straight to them and ask them questions and this happens day and night. I mean they are literally on the phone the whole time.

Third, the idealistic world of transformative accommodation is a world without boundaries. Shachar asserts that it 'refrains from enforcing externally imposed norms on the group'. ${ }^{170}$ It is questionable, however, whether this could or should always be the case. Surely the state would and should be obligated to impose its norms where a group's nomos required (say) human sacrifice? For Shachar, it is the lack of imposed minimal standards that distinguishes transformative accommodation from contingent accommodation. ${ }^{171}$ However, without explicit 'minimal standards' to guide interactions between the state and the group, implicit ideas about minimal standards will form anyway but would be hidden and opaque. Minimal standards are required. The crucial point is that the establishment and re-establishment of these minimal standards requires the visible dialogue between nomoi groups, the state and citizen-insiders.

Fourth, Shachar's scheme is often aimed at achieving integration rather than accommodation. ${ }^{172}$ She talks, for instance, of 'reaching a resolution [which] means

\footnotetext{
${ }^{169}$ And this could be understood using Weber's understanding of the three types of authority: charismatic, traditional and legal-rational

${ }^{170}$ Shachar (n 12) 125.

${ }^{171}$ Ibid 127.

${ }^{172}$ Although there is no consensus as to the exact meanings that are to be attributed to these words (see, e.g., S Poulter, Ethnicity, Law and Human Rights (Oxford University Press, 1999) 12) we suggest that Shachar's focus
} 
appealing to, and integrating, the operation of two value systems - that of the state and the nomoi group'. ${ }^{173}$ Shachar seems to think that if the right conditions were created then the group will reform itself and will accept the prevailing norms of the state. ${ }^{174}$ This is wishful thinking. It assumes that such prevailing norms exist and that all discriminatory behaviour is equally bad. This is not the case. This can be shown, for instance, in the entrenched and complex differences which continue to exist in relation to discrimination on grounds of sex and sexual orientation. As the presence of religious exceptions in the Equality Act 2010 signifies, ${ }^{175}$ the position of religious groups on these matters is often different to society as a whole and the pace of societal change is faster than that within certain groups. It would be wishful thinking to assume that these differences will simply disappear over time. ${ }^{176}$ The situation is more nuanced than Shachar's account assumes.

Fifth, as Shachar concedes, 'transformative accommodation is admittedly limited in terms of immediate and practical judicial economy,. ${ }^{177}$ This is shown, for example, in the way in which Shachar makes significant demands of the state. She reasons that 'since the state is the most powerful entity, the presumption in the negotiations must be in favor of the group'. ${ }^{178}$ This means that 'generosity at the negotiation stage is required from the state as

\footnotetext{
on integration implies a intention to achieve over time a degree of assimilation whereby differences are reduced. In contrast, the focus on accommodation assumes no such intention. The end goal of accommodation is simply the making of space for such difference to exist within the majority culture.

${ }^{173}$ Shachar (n 12) 130.

174 'Transformative accommodation seeks to create institutional conditions where the group recognizes that its own survival depends on revoking certain discriminatory practices in the interests of maintaining autonomy over sub-matters crucial to the group's distinct nomos': ibid 125.

${ }^{175}$ See Sandberg (n 6) chapter 6.

${ }^{176}$ See, for example, Wilson's insistence that 'religious understandings of the duties and prerogatives within the family break sharply from civil understandings': R F Wilson, 'The Perils of Privatised Marriage' in J A Nichols, (ed) Marriage and Divorce in a Multicultural Context (Cambridge University Press, 2012) 253, 257. However, Wilson's concerns about 'the ceding of jurisdiction of religious bodies' and the 'wholesale withdrawal of state oversight' (ibid 281) would not apply in a system of joint governance requiring cooperation. There is no question of 'pulling the state out of marriage and the family' (ibid 283). Moreover, Wilson's argument against the use of the Arbitration Act by 1996 by Shariah Councils seems to ignore the safeguards explicit in that Act as well as the fact that not all Shariah Councils have this objective. The Shariah Council in our study did not.

${ }^{177}$ Shachar (n 12) 130.

${ }^{178}$ Ibid 129.
} 
the stronger party'. ${ }^{179}$ For Shachar, the appeal of transformative accommodation is that it 'offers major advantages of a more lasting import'. ${ }^{180}$ However, this means that it is unlikely to have much political appeal given short-term thinking and the low level at which the debate occurs in the media and in public life. ${ }^{181}$ More so than the other varieties of joint governance Shachar identifies, transformative accommodation is vague and unrealistic. ${ }^{182}$

\section{CONCLUSIONS}

Our empirical findings suggest that Shachar's Multicultural Jurisdictions allows us to make a number of important steps forward. As Phillips rightly observed, Shachar's starting point is compelling: it should be possible to refuse the choice between culture and rights and 'it ought to be possible to recognise that some individuals are coerced by cultural and religious pressures without concluding that all individuals are'. ${ }^{183}$ Shachar is correct to reject the easy 'either/or' approaches, 'opening the door to newer, more complex, and more attractive state and group-based possibilities' ${ }^{184}$ The notion of joint governance recognises how 'nomoi communities are living entities' which 'have ample resources for re-interpretations which permit them to preserve their nomos while adaptively responding to change'. ${ }^{185}$

However, whilst Shachar follows a host of other scholars in recognising the fluid nature of identities that co-exist, interact and mutate, ${ }^{186}$ the variants of joint governance she proposes fail to pay sufficient attention to the agency of the citizen-insider. Indeed, Shachar's

\footnotetext{
${ }^{179}$ Ibid 130.

${ }^{180}$ Ibid 130.

${ }^{181}$ See Kabir (n 11) and A Bradney, 'Some Sceptical Thoughts about the Academic Analysis of Law and Religion in the United Kingdom' in N Doe and R Sandberg, Law and Religion: New Horizons (Peeters, 2010) 299.

${ }^{182}$ See, for example, Levy's criticism that transformative accommodation is used 'as an excuse for wishful thinking': J T Levy, 'Sexual Orientation, Exist and Refuge' in Eisenberg and Spinner-Halev (n 14) 172, 174.

${ }^{183}$ Phillips (n 23) 152, 126.

${ }^{184}$ Shachar (n 12) 146.

${ }^{185}$ Ibid 140.

${ }^{186}$ Fournier calls the approach 'liberal-legal pluralism' because its 'conceptual apparatus' is 'closely associated with the development of identity politics as a way of framing human societies, especially in modern, Western, multicultural and multi-ethnic states'. See P Fournier, Muslim Marriage in Western Courts: Lost in

Transplantation (Ashgate 2011) 65.
} 
much-lauded concept of transformative accommodation is ironically one of the least useful of the variants of joint governance which she identifies. Although its intentions are mostly laudable, the concept is vague and idealistic. ${ }^{187}$ We suggest that a fusion of three of the other variants of joint governance (excluding federal-style accommodation), if understood in a broader way which gives greater emphasis to agency, may point to a clearer way forward. The temporal and consensual accommodation models provide for a system which allows groups to have authority at certain times and then permits the citizen-insider to choose when to come under that authority. The consensual accommodation model also underscores the importance of the question of consent. There is a need to ensure that choice is free and informed and, if we reject Shachar's insistence that consent is a 'one-time choice', then there is a need to ensure that people can move from system to system. This could all be facilitated using insights derived from the contingent model of accommodation whereby recognition is given by the state subject to an oversight function underpinned by a guiding principle. There is a need for visible cooperation between the nomoi group and the state in dialogue with the citizen-insider. This could lead to the negotiation and re-negotiation of minimal standards which could possibly be maintained by means of a system of registration and inspection developed through a dialogue between the state, the group and citizen-insiders. This could be enhanced by a central guiding principle that the welfare of the group insider is paramount. ${ }^{188}$

As Shachar concedes, 'joint governance does not provide a perfect solution to the multiculturalism paradox'. Rather, as she states, its main contribution 'is to take into

\footnotetext{
${ }^{187}$ See Phillips' judgment that it is 'unclear whether the incentive structure Shachar envisages really would have such positive effects' (Phillips (n 23) 153).

${ }^{188}$ There is a need, however, to give greater thought as to how state laws and nomos will interact. The notion of 'inter-legality' proposed by de Sousa Santos may be useful here. Inter-legality is described as a process rather than an outcome where 'elements of a dominant legal order [or a normative order], both national and international and ... the frames of meaning that constitute these orders, [are adopted] into the practice of a local legal order and/or the other way round'. The approach stipulates that different normative orders cannot be said to have a separate existence from one another rather normative orders are interconnected: B de Sousa Santos Towards a New Legal Common Sense. Law, Globalization, and Emancipation (Butterworths 2002) 191-192.
} 
consideration the interests of all three participants in the multicultural triad'. ${ }^{189}$ However, our re-examination of Shachar's proposals in light of our empirical findings suggests that this focus leads her to make two main mistakes. The first is her emphasis upon the group in the singular. As the phenomenon of forum shopping shows, religious groups are not homogeneous entities. The choice for the citizen-insider is not simply between group or state, it is between different variants of the group (and indeed different manifestations of the state). The second mistake is that all her variants of joint governance take an institutional approach which focuses upon the interaction of state and group. The citizen-insider is simply the one over whom the group and state fight. The needs, motives and feelings of the citizen-insider are absent from the analysis. This means that Shachar's variants of joint governance ultimately fail to fulfil the main function she describes: she writes that 'joint governance allows individuals the opportunity to self-select their jurisdictions' ${ }^{190}$ We have set out above how a re-working and combining of her variant models can provide a potential solution which more closely achieves the goal. After all, Shachar's insight is by no means new. ${ }^{191}$ It is actually a return to something that has been lost. The English legal system has long accepted and administered different forms and sources of law. ${ }^{192}$ There is no reason why this cannot be achieved in the twenty-first century.

\footnotetext{
${ }^{189}$ Shachar (n 12) 150.

${ }^{190}$ Ibid 143.

${ }^{191}$ This subjective approach has been adopted by several legal pluralist thinkers who rather than simply supporting Charles Taylor's notion of multiculturalism (n 39) also adhere to his philosophy of the modern self and dialogical characteristics of identity (found in C Taylor, Sources of the Self: The Making of the Modern Identity (Cambridge University Press 1988) and C Taylor Human Agency and Language (Cambridge University Press 1993). For examples of this approach see M M Kleinhans and R A Macdonald 'What is a Critical Legal Pluralism?' (1997) 12(2) Canadian Journal of International Law and Society 25 and A R Jackson, 'A Critical Legal Pluralist Analysis of the Begum Case' (2010) 6(10) Osgoode Hall Law School Comparative Research in Law and Political Economy Research Paper Series, Research Paper No. 46/2010) 1.

${ }^{192}$ See Tamanaha (n 19) 180 who suggests that the medieval period was characterised by a 'radical state of legal pluralism' drawing upon the work of Berman (HJ Berman, Law and Revolution: The Formation of the Western Legal Tradition (Harvard University Press 1983) and Ullmann (W Ullmann, The Medieval Idea of Law (Barnes \& Noble 1969)).
} 